\title{
The Selective Inhibitory Activity of a Fusaricidin Derivative on a Bloom-Forming Cyanobacterium, Microcystis sp. ${ }^{\text {[s }}$
}

\author{
So-Ra Ko ${ }^{1 \dagger}$, Young-Ki Lee ${ }^{2 \dagger}$, Ankita Srivastava ${ }^{1}$, Seung-Hwan Park ${ }^{3}$, Chi-Yong Ahn ${ }^{1}$, and Hee-Mock Oh $^{1 *}$ \\ ${ }^{1}$ Cell Factory Research Center, Korea Research Institute of Bioscience and Biotechnology (KRIBB), Daejeon 34141, Republic of Korea \\ ${ }^{2}$ IPst Company, Daejeon 35209, Republic of Korea \\ ${ }^{3}$ Infections Disease Research Center, Korea Research Institute of Bioscience and Biotechnology (KRIBB), Daejeon 34141, Republic of Korea
}

\author{
Received: April 14, 2018 \\ Revised: October 16, 2018 \\ Accepted: October 25, 2018 \\ First published online \\ October 26, 2018 \\ ${ }^{*}$ Corresponding author \\ Phone: +82-42-860-4321; \\ Fax: +82-42-860-4594; \\ E-mail: heemock@kribb.re.kr \\ ${ }^{\dagger}$ These authors contributed \\ equally to this work. \\ S upplementary data for this \\ paper are available on-line only at \\ http://jmb.or.kr. \\ pISSN 1017-7825, eISSN 1738-8872 \\ Copyright@ 2019 by \\ The Korean Society for Microbiology \\ and Biotechnology
}

\begin{abstract}
Fusaricidin analogs, produced by Paenibacillus polymyxa, were tested for selective control of a major bloom-forming cyanobacterium, Microcystis sp. Fusaricidin (A and B mixtures) and four analogs were isolated from P. polymyxa E681 and investigated for their inhibition of cyanobacterial cell growth. Among the four fusaricidin analogs, fraction $915 \mathrm{Da}$ (designated as Fus901) showed growth inhibition activity for Microcystis aeruginosa but not for Anabaena variabilis and Scenedesmus acutus. Microcystin concentration decreased up to $70 \%$ and its content per cell also decreased over $50 \%$ after 3 days. Fusaricidin exhibited growth inhibition against Gram-positive bacteria but Fus901 did not. Molecular weights of fusaricidin A and B were $883 \mathrm{Da}$ and $897 \mathrm{Da}$, whereas that of Fus901 was $915 \mathrm{Da}$. Structure analysis by a ringopening method revealed a linear form for Fus901. Expression of the pod gene related to oxidative stress was increased 2.1-fold by Fus901 and that of $m c y D$ decreased up to $40 \%$. These results indicate that Fus901 exerts oxidative stress against M. aeruginosa. Thus, Fus 901 can be used as a selective cyanobactericide without disturbing the ecological system and could help in decreasing the microcystin concentration.
\end{abstract}

Keywords: Bloom control, cyanobacteria, fusaricidin, Microcystis, Paenibacillus polymyxa

\section{Introduction}

Freshwater blooms are generally formed by the uncontrolled growth of cyanobacteria, which can produce toxins such as microcystin (MC), nodularin, and anatoxin. MC is encoded by the mcy gene cluster [1]. The $m c y A B C D E F G H I J$ genes are transcribed bidirectionally from a central promoter between $m c y A$ and $m c y D$. Three peptide synthetases are encoded by $m c y A B C, m c y D$ encodes a modular polyketide synthase, $m c y E$ and $m c y G$ encode peptide synthetase and polyketide synthase, respectively, and $m c y J, F$ and $I$ are putatively involved in tailoring, while $m c y H$ is involved in toxin transport [2,3]. Polymerase chain reaction (PCR) amplification of the $m c y A,-B$ and $-C$ genes has been applied for the detection of potentially toxic Microcystis [4]. Two polyketide synthase modules of $m c y D$ with another two polyketide synthases ( $m c y E$ and $m c y G$ ) are responsible for the synthesis of the unique Adda (3-amino- 9-methoxy-2,6,8-trimethyl-10-phenyl-4,6-decadienoic acid) that is used to detect MCs by the protein phosphatase inhibition (PPI) assay [3].

The toxicity of MCs, along with their environmental and economic impact, have triggered the development of methods for the treatment of these toxins [5]. Many chemical and physical methods, such as adsorption, chlorination, oxidation, and ozonation, have been applied to degrade stable MCs. However, until now, only a few biological methods have been reported.

Paenibacillus polymyxa is commonly found in many mineral deposits and the rhizosphere [6]. P. polymyxa strains produce two types of peptide antibiotics. One antibacterial group includes polymyxins and polypeptins. The other, which includes fusaricidin A, B, C, and D, is active against fungi and Gram-positive bacteria [7]. Fusaricidins have a ring structure composed of six amino acid residues in addition to 15-guanidino-3-hydroxypentadecanoic acid 
A

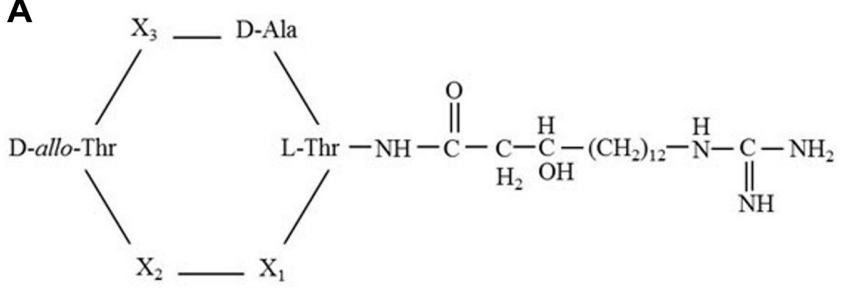

B

\begin{tabular}{ccccc}
\multirow{2}{*}{ Type } & \multicolumn{3}{c}{ Amino acid positions } & $(\mathrm{M}+\mathrm{H})^{+}$ \\
\cline { 2 - 4 } & $\mathrm{X}_{1}$ & $\mathrm{X}_{2}$ & $\mathrm{X}_{3}$ & \\
\hline Fusaricidin A & D-Val & L-Val & D-Asn & 883 \\
\hline Fusaricidin B & D-Val & L-Val & D-Gln & 897 \\
\hline
\end{tabular}

Fig. 1. (A) Primary structure of the fusaricidin-type lipopeptide antibiotics. $X_{1}, X_{2}$, and $X_{3}$ indicate three variable positions in fusaricidins. (B) Amino acid substitutions at three variable positions in previously reported fusaricidins and the molecular weights of the fusaricidins.

(GHPD). The general peptide sequence of the fusaricidins was determined to be L-Thr-X1-X2-D-allo-Thr-X3-D-Ala (Fig. 1A). A $\beta$-hydroxy fatty acid is attached to the $\mathrm{N}$ terminal L-Thr via an amide linkage and the peptide is cyclized by an ester bond between the C-terminal D-Ala and the $\beta-O H$ group of the $\mathrm{N}$-terminal L-Thr. The antimicrobial activity of the fusaricidins varies depending on the amino acids at three variable positions (Fig. 1B) [8].

In this study, we report that one of the fusaricidin analogs has growth inhibition and can decrease intracellular MC content as well. The analog displayed no growth inhibition activity against Gram-positive bacteria. Simultaneously, structural analysis was also performed.

\section{Materials and Methods}

\section{Strains and Culture Conditions}

Anabaena variabilis NIES 23 and Scenedesmus acutus NIES 94 were obtained from the National Institute for Environmental Studies (NIES), Japan. M. aeruginosa KW was isolated from freshwater in Korea. The strains were grown in BG-11 liquid medium ( $\mathrm{pH} 7.5$ ) under $120 \mu \mathrm{mol}$ Photons $/ \mathrm{m}^{2} / \mathrm{s}^{1}$ provided by cool white fluorescent tubes at $27 \pm 1^{\circ} \mathrm{C}$. Micrococcus luteus (KCTC 1056), Bacillus subtilis (KCTC 1022), Staphylococcus aureus (KCTC 1621), Staphylococcus aureus (KCTC 1916), and Escherichia coli (KCTC 2443) were obtained from Korean Collection for Type Cultures (KCTC), and Erwinia carotovora was provided by Dr. Seung-Hwan Park (KRIBB, Korea). P. polymyxa E681, which was isolated from the roots of winter barley in the Republic of Korea, was cultured in Katznelson and Lochhead medium (KL medium) [9].
Purification of Fusaricidins and Its Analogs

P. polymyxa E681 was grown in $5 \mathrm{~L}$ of $\mathrm{KL}$ medium at $27^{\circ} \mathrm{C}$ until they reached the end of the stationary phase $(24 \mathrm{~h})$. The liquid culture medium was then centrifuged $(12,000 \times g, 30 \mathrm{~min})$, filtered through $0.2-\mu \mathrm{m}$ filters and heated at $110^{\circ} \mathrm{C}$ for $10 \mathrm{~min}$. The clarified culture medium was then applied to a CM-Trisacryl column ( 2 by $10 \mathrm{~cm}$ ) equilibrated in $25 \mathrm{mM}$ Tris- $\mathrm{HCl}(\mathrm{pH} 8.5)$. A $\mathrm{NaCl}$ gradient of $100 \mathrm{ml}(0$ to $0.5 \mathrm{M})$ was used in the same buffer to elute the active components at a flow rate of $1 \mathrm{ml} / \mathrm{min}$. A fraction $(1 \mathrm{ml})$ was collected and tested for antagonistic activities. The active fractions were pooled, diluted three times with Milli-Q water, and applied to another CM-Trisacryl column $(2$ by $5 \mathrm{~cm})$. Purified materials were eluted with $30 \mathrm{ml}$ of $0.1 \mathrm{M} \mathrm{NH}_{4} \mathrm{OH}$ at $\mathrm{pH}$ 11 and were concentrated and further purified with a $\mathrm{C}_{18}$ Sep-Pack cartridge (Waters, USA) by following the manufacturer's protocol. Active compounds were eluted from the cartridge in 100\% methanol. The methanol was evaporated under reduced pressure and the antagonistic factor was obtained as a white powder that was soluble in methanol.

Mixtures of fusaricidin A and B (denoted as fusaricidin) and its four analogs were isolated from the methanol extract of P. polymyxa E681 by high-pressure liquid chromatography (HPLC). The methanol extract of the cell pellet was analyzed by LC/MS (Shimadzu, Japan) using a mixed solvent of water and acetonitrile containing $0.1 \%$ formic acid at a rate of $0.2 \mathrm{ml} / \mathrm{min}$. To make the fusaricidin linearized, it was hydrolyzed by $\mathrm{MeOH}-\mathrm{H}_{2} \mathrm{O}-28 \%$ aqueous $\mathrm{NH}_{3}$ (4:1:1, $\left.\mathrm{pH} 9.0\right)$ or esterase for $24 \mathrm{~h}$ according to the method of Kuroda et al. [8].

\section{Growth Inhibition Activity Assays}

The growth inhibition activity of purified fusaricidin and its analogs was measured against Gram-positive and Gram-negative bacteria using the disk diffusion method. LB plates were spread with Gram-positive bacteria (M. luteus KCTC 1056, B. subtilis KCTC 1022, S. aureus KCTC 1621 and S. aureus KCTC 1916) and Gram-negative bacteria (E. coli KCTC 2443 and E. carotovora). Also, for polymyxin E activity, P. polymyxa E681 was cultured in $\mathrm{KL}$ medium at $30^{\circ} \mathrm{C}$ for $24 \mathrm{~h}$. After centrifugation of the culture, the cell pellet was extracted with methanol. The growth inhibition of the mixture of cell extract and supernatant were measured using the disk diffusion method.

\section{Chlorophyll- $a$ and Cell Count}

Isolated M. aeruginosa KW was cultured in BG-11 liquid medium (pH 7.5) under $120 \mu \mathrm{mol}$ Photons $/ \mathrm{m}^{2} / \mathrm{s}^{1}$ provided by cool white fluorescent tubes at $27 \pm 1^{\circ} \mathrm{C}$. The cell numbers of $M$. aeruginosa were counted using an optical microscope. Before counting, the cell suspensions of $M$. aeruginosa were briefly sonicated to disperse any aggregated cell clusters. To determine the chlorophyll- $a$ fraction, samples were filtered using filter paper (Whatman GF/C), then extracted using chloroform-methanol (2:1 (v/v)) [10]. The concentration of chlorophyll- $a$ was then measured by a Turner Quantech fluorometer (Barnstead/Thermolyne, USA) based on a 
Table 1. Primers designed for real-time PCR.

\begin{tabular}{lll}
\hline Gene name & \multicolumn{1}{c}{ Forward primer $\left(5^{\prime}-3^{\prime}\right)$} & \multicolumn{1}{c}{ Reverse primer $\left(5^{\prime}-3^{\prime}\right)$} \\
\hline pod & GCCGTTTTCGATCAAGAGTT & GGATGGGATTGGACGTATTG \\
sodB & ACACACTTCCCCCTTTACCC & GCCGGTTTTGGTAACTTTGA \\
$m c y D^{\mathrm{a}}$ & GGTTCGCCTGGTCAAAGTAA & CCTCGCTAAAGAAGGGTTGA \\
$16 \mathrm{~S}$ rRNA & GGACGGGTGAGTAACGCGTA ${ }^{\mathrm{b}}$ & CCCATTGCGGAAAATTCCCC $^{\mathrm{c}}$ \\
\hline
\end{tabular}

${ }^{\mathrm{a}}$ Kaebernick et al. (2000) [3]

${ }^{\text {b}}$ Urbach et al. (1992) [27]

${ }^{\circ}$ Nübel et al. (1997) [28]

predetermined standard curve programmed into the fluorometer. A blank sample of chloroform was measured and all the readings were readjusted with the blank sample reading.

\section{Analysis}

To determine the microcystin concentration by PPI assay, 5-ml sample aliquots were filtered through a Whatman GF/C filter. The microcystin in the filter papers was extracted with 5\% acetic acid, purified with a Sep-Pak cartridge, and then diluted with $100 \%$ methanol. The PPI assay was performed as described by Ward et al. [11]. Briefly, the diluted protein phosphatase 1 (10 $\mu \mathrm{l})$ was added to $25 \mu \mathrm{l}$ of sample. After pre-incubation for $1 \mathrm{~min}, p$ nitrophenol $(100 \mu \mathrm{l})$ was added and measured after $22 \mathrm{~min}$ at $405 \mathrm{~nm}$ on a microplate reader (Sunrise, Tecan, USA). All enzyme assays were conducted in triplicate. Significant differences $(p<0.05)$ between the results were determined using a $t$-test.

\section{RNA Extraction and Real-Time PCR}

To study whether Fus901 could affect the expression of toxinproducing gene and antioxidant defense-related genes such as the peroxidase $(p o d)$ and superoxide dismutase $(\operatorname{sod} B)$ genes, qRTPCR was carried out to determine the $m c y D$, pod, and $\operatorname{sodB}$ expression levels in Fus901-treated cells (BG11 media, $48 \mathrm{~h}$ incubation, final concentration $1 \mu \mathrm{g} / \mathrm{ml}$ ) relative to the control cells and normalized with the expression of the reference gene, $16 \mathrm{~S}$ rRNA, as described by Chini et al. [12].

Total RNA was isolated with the RiboPure-Bacteria Kit (Ambion, USA) according to the manufacturer's instructions and treated with DNase I at $30^{\circ} \mathrm{C}$ for $30 \mathrm{~min}$. First-strand cDNA synthesis, using $0.5 \mu \mathrm{g}$ of RNA as a template, was carried out in a total volume of $20 \mu \mathrm{l}$ using the iScript cDNA Synthesis Kit (BioRad, USA) according to the manufacturer's instructions. Any residual DNA was eliminated by incubating RNA preparations for $5 \mathrm{~min}$ at $42^{\circ} \mathrm{C}$ with the gDNA Wipeout Buffer (Qiagen, Germany) and the cDNA synthesis reaction was carried out at $42^{\circ} \mathrm{C}$ for $15 \mathrm{~min}$ in duplicate with or without iScript reverse transcriptase, followed by $3 \mathrm{~min}$ incubation at $95^{\circ} \mathrm{C}$ to inactivate the enzyme. PCR primers for the three genes are listed in Table 1. Real-time PCR was performed in $20 \mu$ of a reaction mixture containing $10 \mu \mathrm{l}$ of iTaq SYBR Green Supermix with ROX (Bio-Rad, USA), $1 \mu \mathrm{l}(10 \mathrm{pmol} / \mu \mathrm{l})$ each of forward and reverse primers, $1 \mu \mathrm{l}$
cDNA and $7 \mu \mathrm{l}$ distilled water. The amplification reactions were performed by a Chromo4 Four-Color Real-Time PCR Detector (Bio-Rad, USA) under the following conditions: one cycle at $95^{\circ} \mathrm{C}$ for $5 \mathrm{~min}$, followed by 40 cycles of $95^{\circ} \mathrm{C}$ for $30 \mathrm{sec}, 61^{\circ} \mathrm{C}$ for $1 \mathrm{~min}$, and $72^{\circ} \mathrm{C}$ for $20 \mathrm{sec}$ [13].

A threshold cycle $\left(C_{\mathrm{T}}\right)$ value was determined for each amplification plot. $C_{\mathrm{T}}$ values were standardized to $16 \mathrm{~S}$ rRNA values. The quantitative PCR results were represented as the foldchange in target gene expression. The expression ratio was calculated based on the formula of $2^{-\Delta A C}$ [14].

\section{Results}

\section{Growth Inhibition of Fusaricidin Analogs}

To investigate the growth inhibition, the four analogs and fusaricidin were added to $M$. aeruginosa KW culture (initial cell density $2.37 \pm 0.15 \times 10^{7}$ cells $/ \mathrm{ml}, n=3$ ) at $1 \mu \mathrm{g} / \mathrm{ml}$ and incubated at $27^{\circ} \mathrm{C}$ for 3 days. Fraction 915 among the

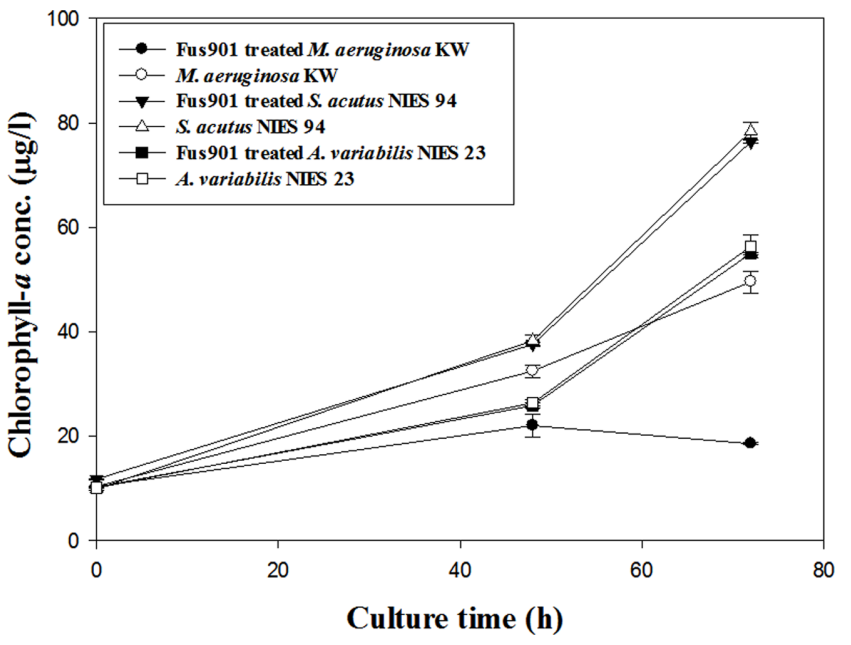

Fig. 2. The chlorophyll- $a$ concentration of $A$. variabilis NIES 23, S. acutus NIES 94, and M. aeruginosa KW when Fus901 was added.

Controls are A. variabilis NIES 23, S. acutus NIES 94, and M. aeruginosa KW without Fus901 treatment. 
four analogs showed potent growth inhibition against M. aeruginosa (data not shown). To investigate the specificity of fraction 915, another cyanobacterium, A. variabilis NIES 23 and a green alga, S. acutus NIES 94, were also treated. After 3 days, the growth of A. variabilis NIES 23 and S. acutus NIES 94 was not inhibited, but chlorophyll- $a$ concentration of $M$. aeruginosa KW decreased from $49.6 \mu \mathrm{g} / 1$ to $18.6 \mu \mathrm{g} / 1$ (Fig. 2). Fraction 915 showing growth inhibition was designated as Fus901. Moreover, the Chlorophyll- $a$ concentration of M. aeruginosa KW was also decreased when Fus901 was added in the middle of the growth phase (Fig. S3).

\section{Decrease in MC Content by Fus901}

After 3 days of cultivation, the intracellular MC concentration in Fus901-treated M. aeruginosa KW decreased up to $70 \%$, while extracellular concentration showed no difference, when compared to control (Fig. 3A). These results indicated that Fus901 decreased MC content within M. aeruginosa cells. To confirm this, MC content per cell was determined after treatment with Fus901. The initial cell concentration

\section{A}

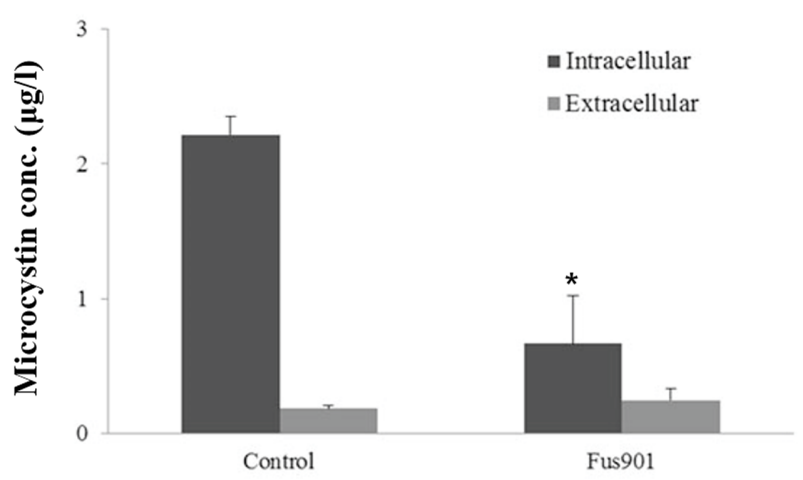

B

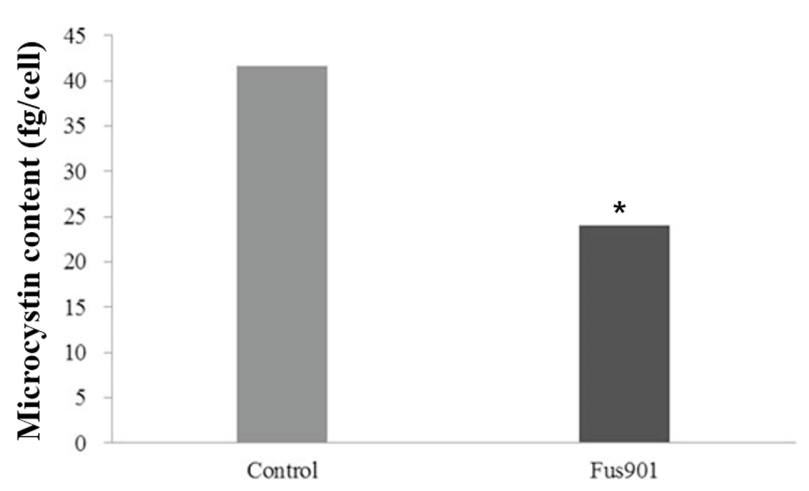

Fig. 3. Effect of Fus901 on MC production by M. aeruginosa KW.

(A) Comparison of total MC concentration between control and treatment. (B) Comparison of MC content per cell. Data are means \pm SD $(n=3) .{ }^{*} p<0.05$ indicate significant differences compared with the corresponding controls. of $M$. aeruginosa $\mathrm{KW}$ was $2.37 \pm 0.15 \times 10^{7}$ cells $/ \mathrm{ml}$ and the cell concentrations of control and Fus901-treated samples after $72 \mathrm{~h}$ were $5.32 \times 10^{7}$ and $2.77 \times 10^{7}$ cells $/ \mathrm{ml}$, respectively. The MC content was $41.6 \mathrm{fg} / \mathrm{cell}$ in control, whereas that of Fus901-treated cells was 24.0 fg/cell (Fig. 3B).

\section{Growth Inhibition Activity of Fus901}

Growth inhibition activity was tested against four Grampositive bacteria (M. luteus, B. subtilis, and Staphylococcus sp. KCTC 1621 and 1916) and two Gram-negative bacteria (E. coli and E. carotovora). Various concentrations $(0.625$, $1.25,2.5,5.0$, and $10 \mathrm{mg} / \mathrm{ml}$ ) of Fus901 were tested to check its growth-inhibiting activity on the M. luteus (Fig. S4). Fusaricidin and Fus 901 were tested at $1 \mathrm{mg} / \mathrm{ml}$ concentration and crude extract $(20 \mathrm{mg} / \mathrm{ml})$ of polymyxin E produced by P. polymyxa E681 was also used. Polymyxin E is known to have strong growth inhibition activity against Gramnegative bacteria [15]. Whereas fusaricidin showed strong growth inhibition activity on the tested Gram-positive bacteria, Fus901 completely lost its growth inhibition activity against the Gram-positive bacteria (Fig. 4A). Similar to fusaricidin, Fus901 showed no growth inhibition activity on E. coli or E. carotovora (Fig. 4B).

\section{Structure Analysis of Fus901}

Fus901 and fusaricidin linearized by a ring-opening method were analyzed by LC/MS/MS. The ring-opening

A

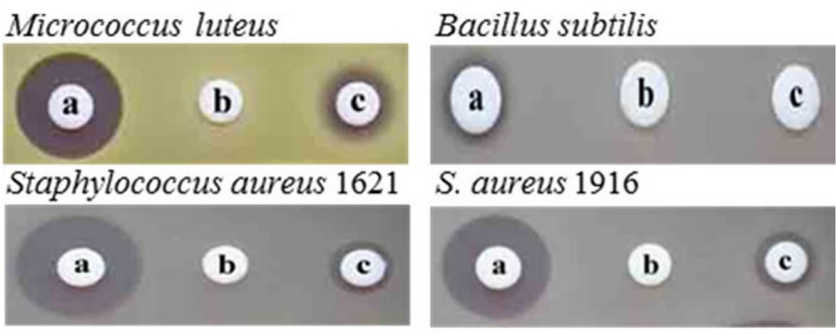

B
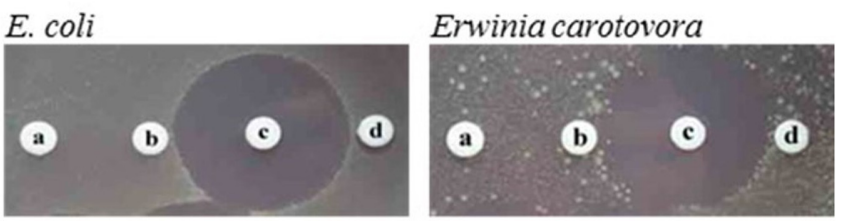

Fig. 4. Growth inhibition activity of Fus901 compared to the activity of intact fusaricidin.

(A) Growth inhibition activity against Gram-positive bacteria, (B) Gram-negative bacteria. a, fusaricidin $1 \mathrm{mg} / \mathrm{ml}$; b, Fus901 $1 \mathrm{mg} / \mathrm{ml}$; (A)-c and (B)-d, methanol; (B)-c, crude extract $(20 \mathrm{mg} / \mathrm{ml})$ of polymyxin E produced by P. polymyxa E681. 


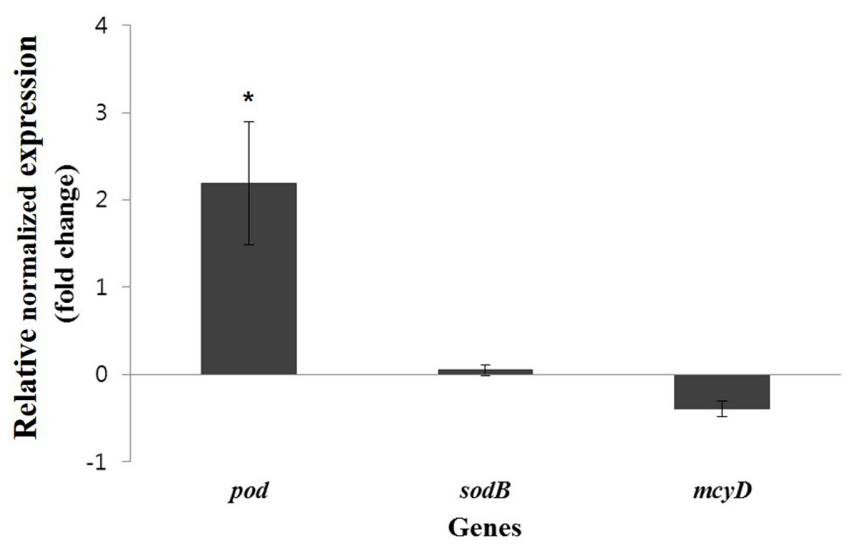

Fig. 5. Level of $m c y D$, pod, and $\operatorname{sodB}$ mRNA expression in M. aeruginosa KW as a response to Fus901 by real-time PCR. The error bar is the mean $\pm \mathrm{SD}\left({ }^{*} p<0.05\right)$.

method was carried out by addition of $\mathrm{NaOH}$ and esterase. The methanol extract of the Fus901 was analyzed by LC/ MS/MS. The $(\mathrm{M}+\mathrm{H})^{+}$ion peak of Fus901 was 915 at a retention time of $8.23 \mathrm{~min}$ (Fig. S1A), while those of fusaricidin were 883 and 897 at retention times of $10.04 \mathrm{~min}$ and $10.42 \mathrm{~min}$, respectively (Figs. S1B and S1C). Like Fus901, the $(\mathrm{M}+\mathrm{H})^{+}$ion peak of ring-opened fusaricidin by treatment of esterase and $\mathrm{NaOH}$ was 915 with retention times of $10.20 \mathrm{~min}$ and $10.70 \mathrm{~min}$ (Figs. S1B and S1C). From the LC/MS/MS results, Fus901 was identified as a linearized form with a broken ester bond (Fig. S2).

\section{Effect of Fus901 on $m c y D$ Transcription and Antioxidant Defenses}

A modular polyketide synthase is encoded by $m c y D$, involved in the synthesis of the $\beta$-amino acid Adda that is responsible for the toxicity of the microcystins [2]. Moreover, McyD is essential in microcystin synthesis and the lack of this protein results in the absence of microcystin synthesis [3]. Thus, $m c y D$ was considered for expression studies.

Relative transcriptional change by Fus901 based on the housekeeping gene, 16S rRNA, is shown in Fig. 5. The level of pod transcript increased 2.1-fold when M. aeruginosa KW was grown under Fus901. Meanwhile, sodB transcript level hardly changed. The level of $m c y D$ transcript slightly decreased (up to $40 \%$ ) and this result corresponded with the decrease of MC content.

\section{Discussion}

Several control techniques for algal bloom have been developed such as the use of yellow loess [16] and clay [17] Even though effective, yellow loess and clay can cause secondary effects on other aquatic organisms. The application of chemical cyanobactericidal agents such as copper sulfate [18] and hydrogen peroxide [19] are also effective in controlling cyanobacterial blooms within a short time, but these chemicals can inhibit the entire phytoplankton community and cause water quality deterioration [20]. Recent studies have focused on the identification of bacteria capable of inhibiting or degrading algal blooms in marine and freshwater environments [21]. Application of biological agents, such as bacteria [22], viruses [23] and planktonic ciliates [24], in aquatic systems, faces difficulty posed by the demands of high bacterial cell density. Five strains (HYY0510-SK04, HYY0511-SK09, HYK0512-SK12, HYK0512-PK04 and HYY0512-PK05) isolated by Kang et al. [22] degraded Stephanodiscus hantzschii cells when those bacteria were inoculated at a concentration of $\geq 10^{7}$ cells $/ \mathrm{ml}$. Moreover, these bacteria showed growth inhibition activity against several algae and cyanobacteria. Mayali and Doucette [24] isolated Cytophaga strain 41DBG2 from Gulf of Mexico waters which showed algicidal activity against Karenia brevis (Dinophyceae), when added at $\geq 10^{6}$ cells $/ \mathrm{ml}$.

Several aquatic plants produce metabolites inhibiting the growth of algae and cyanobacteria. These substances are known as allelochemicals. Many allelochemicals have been isolated and identified. Nakai et al. [25] reported that macrophyte Myriophyllum spicatum released allelopathic polyphenols, which inhibited the growth of M. aeruginosa at $1.26 \mathrm{mg} / 1$. However, none of these methods can specifically control algal blooms without causing problems to other organisms in aquatic environments.

Tandem mass spectrophotometry (MS/MS) has been used for elucidating the primary structures of peptides or proteins. In this study, to investigate the structural differences in the four analogs derived from fusaricidin, we purified them by HPLC. The $(\mathrm{M}+\mathrm{H})^{+}$ion peaks of fusaricidin A, B, C, and D were 883, 897, 947, and 961, respectively. But, those of the four analogs were 915, 929, 943, and 957, respectively (data not shown). Because fusaricidin A and B comprise a large proportion of the fusaricidin produced by P. polymyxa E681, we made a ringopened fusaricidin (A and $\mathrm{B}$ mixture) by $\mathrm{NaOH}$ treatment and compared those structures with Fus901 by MS/MS analysis. The $(\mathrm{M}+\mathrm{H})^{+}$ion peak of ring-opened fusaricidin was 915 and this molecular weight of $\mathrm{m} / \mathrm{z} 915$ corresponded with that of Fus901. Ring-opened fusaricidin was probably made by the ring-opening process between 
the $\beta$-carbon atom and the oxygen atom at the $\beta$-position of threonine (Fig. S2A asterisk).

Fusaricidin B showed strong growth inhibition activity against a wide variety of fungi and also had low minimum inhibitory concentration values against Gram-positive bacteria (S. aureus and M. luteus) with $1.56 \mu \mathrm{g} / \mathrm{ml}$. On the other hand, it showed relatively low sensitivity against Gram-negative bacteria (E. coli and P. aeruginosa) [26]. However, Fus901 did not show growth inhibition activity against Gram-positive bacteria or Gram-negative bacteria at $1 \mu \mathrm{g} / \mathrm{ml}$. This indicated that Fus901 is an eco-friendly cyanobactericide that does not disturb other aquatic microorganisms.

A few studies have focused specifically on the MC biosynthesis genes and have shown the effects of single or combined factors on MC synthesis [3]. The current study selected $m c y D$ as representative of decreased MC production and used real-time PCR to analyze the transcript levels of this gene under Fus901 treatment. Expression of mcyD transcript level was slightly decreased (up to 40\%) by Fus901. A decrease in $m c y D$ transcript level resulted in the reduction of MC synthesis. In photosynthetic organisms, environmental stress can create oxidative stress through overproduction of reactive oxygen species, which induce the expression of the superoxide dismutase (SOD) and peroxidase (POD) genes. Under oxidative stress, plants and microalgae respond by increasing antioxidant defenses such as SOD and POD enzymes. Fus901 increased pod gene transcription in $M$. aeruginosa, whereas $s o d B$ transcript level did not change. These results indicated that Fus 901 creates oxidative stress in M. aeruginosa and consequently inhibits the growth of $M$. aeruginosa while also reducing the MC production.

Four fusaricidin analogs were isolated and purified from P. polymyxa E681. One analog, designated Fus901, exhibited highly species-specific growth inhibition on M. aeruginosa. The growth of $M$. aeruginosa was inhibited and the MC concentration also decreased up to $70 \%$ when $M$. aeruginosa was grown in $1 \mu \mathrm{g} / \mathrm{ml}$ of Fus901. MC content also decreased from $41.6 \mathrm{fg} /$ cell to $24.0 \mathrm{fg} /$ cell. Real-time PCR analyses of the $m c y D$ gene under Fus901 revealed that the level of $m c y D$ transcript slightly decreased (0.4-fold) as compared to the control. The level of pod transcript increased in response to Fus901. The data indicated that Fus901 induced oxidative stress in M. aeruginosa. Fus901, unlike fusaricidin, showed no growth inhibition against Gram-positive bacteria. Therefore, Fus901 appears to be a promising cyanobactericide that does not disturb the aquatic ecosystem.

\section{Acknowledgments}

This research was supported by the Basic Core Technology Development Program for the Oceans and the Polar Regions of the National Research Foundation (NRF) funded by the Ministry of Science and ICT (2016M1A5A1027453) and KRIBB Research Initiative Program.

\section{Conflict of Interest}

The authors have no financial conflicts of interest to declare.

\section{References}

1. Dittmann E, Neilan BA, Erhard M, Von Döhren H, Börner T. 1997. Insertional mutagenesis of a peptide synthetase gene that is responsible for hepatotoxin production in the cyanobacterium Microcystis aeruginosa PCC 7806. Mol. Microbiol. 26: 779-787.

2. Tillett D, Dittmann E, Erhard M, von Dohren H, Börner, Neilan BA. 2000. Structural organization of microcystin biosynthesis in Microcystis aeruginosa PCC7806: an integrated peptide-polyketide synthetase system. Chem. Biol. 7: 753-764.

3. Kaebernick M, Neilan BA, Börner T, Dittmann E. 2000. Light and the transcriptional response of the microcystin biosynthesis gene cluster. Appl. Environ. Microbiol. 66: 33873392.

4. Baker JA, Entsch B, Neilan BA, McKay DB. 2002. Monitoring changing toxigenicity of a cyanobacterial bloom by molecular methods. Appl. Environ. Microbiol. 68: 6070-6076.

5. Lawton LA, Cornish BJPA, MacDonald AWR. 1998. Removal of cyanobacterial toxins (microcystins) and cyanobacterial cells from drinking water using domestic water filters. Water Res. 32: 633-638.

6. Zhang S, Raza W, Yang X, Hu J, Huang Q, Xu Y, et al. 2008. Control of fusarium wilt disease of cucumber plants with the application of a bioorganic fertilizer. Biol. Fert. Soils. 44: 1073-1080.

7. Raza W, Yang W, Shen Q-R. 2008. Paenibacillus polymyxa: antibiotics, hydrolytic enzymes and hazard assessment. $J$. Plant Pathol. 90: 419-430.

8. Kuroda J, Fukai T, Konishi M, Ono J, Kurusu K, Nomura T. 2000. LI-F antibiotics, a family of antifungal cyclic depsipeptides produced by Bacillus polymyxa L-1129. Heterocycles 53: 1533-1549.

9. Choi SK, Park SY, Kim R, Lee CH, Kim JF, Park SH. 2008. Identification and functional analysis of the fusaricidin biosynthetic gene of Paenibacillus polymyxa E681. Biochem. Biophys. Res. Comm. 365: 89-95.

10. Wood LW. 1985. Chloroform-methanol extraction of 
chlorophyll a. Can. J. Fish. Aquat. Sci. 42: 38-43.

11. Ward CJ, Beattie KA, Lee EYC, Codd GA. 1997. Colorimetric protein phosphatase inhibition assay of laboratory strains and natural blooms of cyanobacteria: comparisons with highperformance liquid chromatographic analysis for microcystins. FEMS Microbiol. Lett. 153: 465-473.

12. Chini V, Foka A, Dimitracopoulos G, Spiliopoulou I. 2007. Absolute and relative real-time PCR in the quantification of tst gene expression among methicillin-resistant Staphylococcus aureus: evaluation by two mathematical models. Lett. Appl. Microbiol. 45: 479-484.

13. Rinta-Kanto, Western Ouellette AJA, Boyer GL, Twiss MR, Bridgeman TB, Wilhelm SW. 2005. Quantification of toxin Microcystis spp. during 2003 and 2004 blooms in Wastern Lake Eric using quantitative real-time PCR. Environ. Sci. Technol. 39: 4198-4205.

14. Livak KJ, Schmittgen TD. 2001. Analysis of relative gene expression data using real-time quantitative PCR and the $2_{T}^{-\Delta \Lambda C}$ method. Methods 25: 402-408.

15. Choi SK, Park SY, Kim R, Kim SB, Lee CH, Kim JF, et al. 2009. Identification of a Polymyxin synthetase gene cluster of Paenibacillus polymyxa and heterologous expression of the gene in Bacillus subtilis. J. Bacteriol. 191: 3350-3358.

16. Lee YJ, Choi JK, Kim EK, Youn SH, Yang EJ. 2008. Field experiments on mitigation of harmful algal blooms using a sophorolipid-yellow clay mixture and effects on marine plankton. Harmful Algae 7: 154-162.

17. Pan G, Zhang MM, Chen H, Zou H, Yan H. 2006. Removal of cyanobacterial blooms in Taihu lake using local soils. I. Equilibrium and kinetic screening on the flocculation of Microcystis aeruginosa using commercially available clays and minerals. Environ. Pollut. 141: 195-200.

18. Han FX, Hargreaves JA, Kingery WL, Huggett DB, Schlenk DK. 2001. Accumulation, distribution, and toxicity of copper in sediments of catfish ponds receiving periodic copper sulfate applications. J. Environ. Qual. 30: 912-919.
19. Drábková M, Maršálek B, Admiraal W. 2007. Photodynamic therapy against cyanobacteria. Environ. Toxicol. 22: 112-115.

20. Jeong JH, Jin HJ, Sohn CH, Suh KH, Hong YK. 2000. Algicidal activity of the seaweed Corallina pilulifera against red tide microalgae. J. Appl. Phycol. 12: 37-43.

21. Manage PM, Kawabata Z, Nakano SI. 2000. Algicidal effect of the bacterium Alcaligenes denitrificans on Microcystis spp. Aquat. Microb. Ecol. 22: 111-117.

22. Kang YK, Cho SY, Kang YH, Katano T, Jin ES, Kong DS, et al. 2008. Isolation, identification and characterization of algicidal bacteria against Stephanodiscus hantzschii and Peridinium bipes for the control of freshwater winter algal blooms. J. Appl. Phycol. 20: 375-386.

23. Yoshida T, Takashima Y, Tomaru Y, Shirai Y, Takao Y, Hiroishi $S$, et al. 2006. Isolation and characterization of a cyanophage infecting the toxic cyanobacterium Microcystis aeruginosa. Appl. Environ. Microbiol. 72: 1239-1247.

24. Mayali X, Doucette GJ. 2002. Microbial community interactions and population dynamics of an algicidal bacterium active against Karenia brevis (Dinophyceae). Harmful Algae 1: 277293.

25. Nakai S, Inoue Y, Hosomi M, Murakami A. 2000. Myriophyllum spicatum-released allelopathic polyphenols inhibiting growth of blue-green algae Microcystis aeruginosa. Water Res. 34: 3026-3032.

26. Kajimura Y, Kaneda M. 1997. Fusaricidins B, C, and D, new depsipeptide antibiotics produced by Bacillus polymyxa KT-8: isolation, structure elucidation and biological activity. J. Antibiot. 50: 220-228.

27. Urbach E, Robertsin D, Chisholm S. 1992. Multiple evolutionary origins of prochlorophytes within the cyanobacterial radiation. Nature 335: 267-270.

28. Nübel U, Garcia-Pichel F, Muyer G. 1997. PCR primers to amplify $16 \mathrm{~S}$ rRNA genes from cyanobacteria. Appl. Environ. Microbiol. 63: 3327-3332. 